\title{
RANCANG BANGUN SISTEM INFORMASI PENJUALAN FASHION BERBASIS WEB
}

\author{
Budi Sudradjat \\ Email: budi.bst@bsi.ac.id
}

\begin{abstract}
Abstrak
Sistem penjualan di toko H2H Couple Fashion saat ini masih menggunakan cara manual dan sangat sederhana. Pembeli harus datang langsung sehingga tidak efektif dan efisien. Sarana promosi yang ada juga belum memadai sehingga kurang dikenal, hal ini memperkecil peluang untuk mendapatkan pembeli yang potensial. Dengan dibuatnya sistem penjualan online berbasis web diharapkan dapat memberikan kemudahan bertransaksi serta menjadi sarana promosi yang efektif dan efisien dengan jangkauan pasar yang luas serta memberikan kepuasan kepada pelanggan sehingga meningkatkan keuntungan bagi perusahaan. Desain, Pembuatan kode program, Pengujian dan Pendukung, dengan menggunakan alat pemodelan berupa Unifield Modelling Language (UML), Entity Relationship Diagram (ERD) dan teknik pengumpulan data dengan cara observasi, dan wawancara. Sedangkan alat pengembangan aplikasi database menggunakan MySQL dan PHPMyAdmin dan bahasa pemrograman PHP, text editor Adobe Dreamweaver CS6. Aplikasi ini menyediakan informasi produk dan menghasilkan laporan-laporan diantaranya laporan produk dan laporan penjualan.
\end{abstract}

\begin{abstract}
Sales System at H2H Couple Fashion today still use manual and very simple. Buyers must come directly so as not effective and efficient. Means of promotion there is inadequate so poorly known, it is harder to obtain for potential buyers. With the establishment of an online sales system web-based is expected to provide ease of transaction as well as a means of effective and efficient promotion with a wide range of markets and provide satisfaction to customers thereby increasing profits for the company. Design, code creation, testing and support. by using a modeling tool such as a unified Modeling Language (UML), Entity Relationship Diagram (ERD) and data collection techniques by observation, and interviews. While the database application development tools using MySQL and PHPMyAdmin and PHP programming language, Adobe Dreamweaver CS6 text editor. This application provides product information and generate reports including product reports and sales reports.
\end{abstract}

Keywords : Online Sales, Couple Fashion, Online Fashion Store. 


\section{Pendahuluan}

H2H Couple Fashion adalah sebuah toko yang menjual aneka fashion baik pria maupun wanita yang lengkap dan up to date. $\mathrm{H} 2 \mathrm{H}$ Couple Fashion berlokasi cukup strategis, walaupun dipinggiran kota Jakarta, tetapi akses jalan yang sering dilewati kendaraan dari arah Tangerang menuju Jakarta dan sebaliknya, menjadikan $\mathrm{H} 2 \mathrm{H}$ Couple Fashion mudah untuk ditemukan dan selalu menjadi perhatian pengguna jalan. Saat ini $\mathrm{H} 2 \mathrm{H}$ Couple Fashion masih menggunakan sistem penjualan secara manual dan sangat sederhana. Pembeli harus datang langsung ke $\mathrm{H} 2 \mathrm{H}$ Couple Fashion sehingga banyak konsumen yang merasa tidak efektif dan efisien apabila akan berbelanja ke $\mathrm{H} 2 \mathrm{H}$ Couple Fashion karena banyak terkendala jarak dan waktu. H2H Couple Fashion juga belum mempunyai sarana promosi yang memadai, sehingga masih mengandalkan promosi lewat mulut ke mulut dan pemasangan spanduk di depan toko. Hal ini menjadikan $\mathrm{H} 2 \mathrm{H}$ Couple Fashion kurang dikenal, sehingga memperkecil peluang untuk mendapatkan konsumen dari berbagai daerah yang sebenarnya sangat potensial.

Berdasarkan permasalahan yang ada, maka perlu dibangun sistem pengolahan data dan penjualan berbasis web e-commerce pada $\mathrm{H} 2 \mathrm{H}$ Couple Fashion dengan harapan dapat membantu kinerja dan memperluas jaringan perusahaan sekaligus mempermudah dan memperbanyak promosi perusahaan melalui internet sehingga bisa meningkatkan minat pembeli yang pada akhirnya meningkatkan pendapatan perusahaan.

\section{Metode Penelitian}

Peneliti di dalam mendapatkan data sebagai objek penulisan digunakan metode sebagai berikut :

1. Teknik Pengumpulan Data

a. Observasi, yaitu pencarian data dengan pengamatan dan penelitian secara langsung terhadap sistem berjalan pada $\mathrm{H} 2 \mathrm{H}$ Couple Fashion, khususnya pada sistem pendataan barang, proses transaksi, dan promosi

b. Wawancara, yaitu melakukan tanya jawab kepada pihak-pihak yang secara langsung menangani sistem penjualan pada $\mathrm{H} 2 \mathrm{H}$ Couple Fashion yaitu pemilik toko, administrasi toko, kasir toko, dan pelayan toko. Informasi yang didapat dari metode ini berupa keterangan-keterangan mengenai prosedur sistem berjalan.

c. Studi Pustaka yaitu pengumpulan data dengan melihat dari buku yang didapat semasa kuliah dan melalui buku cetak, jurnal ilmiah dan situs internet.

2. Model Pengembangan Sistem

a. Analisa Kebutuhan Sistem, dalam membangun e-commerce $\mathrm{H} 2 \mathrm{H}$ Couple Fashion, yang sebelumnya dokumen masukannya hanya berupa kertas bon, dan dokumen keluaran hanya laporan penjualan, maka interface yang diperlukan untuk mendukung software dalam proses komputerisasi yang akan disediakan adalah tampilan halaman home, login, produk, detail produk, pendaftaran pelanggan, keranjang belanja, testimonial, dan profil.

b. Desain, perancangan desain setelah menganalisa kebutuhan software yang diperlukan adalah sebagai berikut:
1) Rancangan
Database, menggunakan Entity Relationship Diagram untuk menggambarkan tabel-tabel yang ada di program beserta relasi dan tipe datanya. Pemodelan konsep piranti lunak dengan Unified Modelling Languange.

2) Software Architecture, dengan mengunakan pemrograman terstruktur, tahap ini menggambarkan component diagram dan deployment diagram.

c. Code Generation, bahasa pemrograman untuk membuat website e-commerce pada $\mathrm{H} 2 \mathrm{H}$ Couple Fashion ini adalah bahasa pemrograman terstruktur dengan menggunakan PHP, text editor Adobe Dreamweaver CS6. 
d. Testing, blackbox testing adalah salah satu metode pengujian perangkat lunak yang digunakan. Perancang uji memilih input yang valid dan tidak valid dan menentukan output yang benar. Metode ujicoba blackbox memfokuskan pada keperluan fungsional dari software. Karena itu, ujicoba blackbox memungkinkan pengembang software untuk membuat himpunan kondisi input yang akan melatih seluruh syarat-syarat fungsional suatu program.

e. Support, fase perawatan terhadap sistem yang telah dikembangkan dan diimplementasikan. Setelah software diberikan kepada pelanggan, maka kedepannya akan selalu di update sehingga data-data maupun perintahperintah akan selalu mengikuti perkembangan dari bisnis online yang diinginkan. Proses perawatan terus dilakukan secara berkala baik dari sistem maupun terhadap perbaikan sistem apabila terjadi kendala dalam operasionalnya akibat dari masalah teknis maupun non teknis yang tidak terindikasi dalam proses pengembangan sistem. Pemeliharaan sistem adalah cara terbaik untuk menjaga efisiensi sistem yang sudah ada. Pemeriksaan setiap awal dan akhir bulan serta backup data akan dilakukan oleh pihak perusahaan.

\section{Tinjauan Pustaka}

\section{Pengertian Pemrograman Terstruktur}

Menurut Sutabri (2004), "Pemrograman terstruktur merupakan suatu cara mengorganisasi, menyederhanakan, dan meningkatkan kemampuan program supaya mudah dimengerti, dites, dan dimodifikasi".

\section{Pengertian PHP}

Menurut Sukamto dan Shalahuddin (2011), "PHP dibuat pertama kali oleh seorang perekayasa perangkat lunak yang bernama Rasmus Lerdoff. Rasmus Lerdoff membuat halaman web PHP pertamanya pada tahup 1994. PHP4 dengan versi-versi akhir menuju PHP5 sudah mendukung pemrograman berorientasi objek. PHP merupakan bahasa pemrograman yang digunakan untuk pemrograman web".

\section{Pengertian Database MySQL}

Menurut Muhammad Sadeli (2013), "MySQL menggunakan perintah query dan escaps character yang sama dengan PHP. MySQL mempunyai tampilan client yang mempermudah dalam mengakses database dengan kata sandi untuk mengizinkan proses yang akan dilakukan".

\section{Adobe Dreamweaver CS6}

Adobe Dreamweaver CS6 merupakan salah satu aplikasi popular yang digunakan untuk mendesain sekaligus melakukan pemrograman web. Adobe Dreamweaver CS6 memberikan fasilitas untuk mengedit HTML secara visual. Aplikasi ini menyertakan banyak perangkat yang berkaitan dengan pengkodean dan fitur seperti HTML, CSS, hingga JavaScript. Selain itu, aplikasi ini juga memungkinkan pengeditan JavaScript, XML, dan dokumen teks lainnya secara langsung.

\section{Pengertian UML}

Menurut Sukamto dan Shalahuddin (2011), "UML (Unified Modelling Language) merupakan bahasa visual untuk pemodelan dan komunikasi mengenai sebuah sistem dengan menggunakan diagram dan teks-teks pendukung".

UML (Unified Modelling Language) telah menjadi standart dalam merancang suatu sistem visualisasi dan mendokumentasikan sistem piranti lunak. Para pengembang sistem berorientasi objek menggunakan bahasa model untuk menggambarkan, membangun, dan mendokumentasikan sistem yang sedang dirancang. UML (Unified Modelling Language) memungkinkan para anggota team untuk bekerjasama dengan model yang sama dalam merancang suatu sistem yang akan dibuat, dikarenakan dapat mempermudah bagi perancangan dalam merancangnya.

\section{Pengertian ERD}

Menurut Linda Marlinda (2004), "Model Entity Relationship merupakan suatu model 
untuk menjelaskan hubungan antar data dalam basis data berdasarkan suatu persepsi bahwa real word terdiri dari objek-objek dasar mempunyai hubungan atau relasi antar objek-objek tersebut, relasi antar objek dilukiskan dengan menggunakan simbol-simbol grafis tertentu".

\section{Pengertian LRS}

LRS (Logical Record Structure) terdiri dari link -link diantara tipe record. Link ini menunjukkan arah dari satu tipe record lainnya. Banyak link dari Logical Record Structure yang diberi tanda field-field yang kelihatan pada kedua link tipe record. Penggambaran Logical Record Structure mulai dengan menggunakan model yang dimengerti.

\section{Sistem yang Sedang Berjalan}

Sebagai usaha penjualan yang masih menggunakan sistem konvesional, proses yang berjalan pada $\mathrm{H} 2 \mathrm{H}$ Couple Fashion dimulai dengan customer yang datang langsung ke toko H2H Couple Fashion, kemudian memilih produk yang tersedia, jika tidak ada produk yang cocok, maka customer langsung pulang dari toko, jika menemukan produk yang cocok, maka customer memberi konfirmasi cocok kepada pelayan toko. Setelah menerima konfirmasi cocok dari customer, maka pelayan toko membuat nota dan menyiapkan produk yang akan dibeli. Lalu Pelayan menyerahkan nota ke customer, dan menyerahkan produk yang akan dibeli ke kasir. Kemudian berdasarkan nota dari pelayan toko, maka customer melakukan pembayaran ke kasir. Setelah kasir menerima pembayaran berdasarkan nota dari customer, lalu kasir membuatkan kwitansi. Kemudian kasir menyerahkan produk yang dibeli dan kwitansi kepada customer, Setelah menerima produk yang dibeli, kemudian customer pulang dari toko. Berdasarkan nota penjualan dan kwitansi, maka kasir membuat laporan stok harian untuk diserahkan kepada Administrasi. Kemudian berdasarkan laporan stock harian, administrasi membuat laporan stock mingguan untuk diserahkan kepada pemilik toko.

\section{Rancangan Sistem dan Program Usulan.}

Dengan sistem penjualan secara online berbasis web, maka antara penjual dan pembeli tidak bertatap muka secara langsung. Calon pembeli melakukan pembelian melalui media browser. Berikut ini spesifikasi kebutuhan (system requirement) dari sistem belanja online $\mathrm{H} 2 \mathrm{H}$ Couple Fashion:

A1.Pembeli melakukan login untuk bisa berbelanja di $\mathrm{H} 2 \mathrm{H}$ Couple Fashion, apabila belum menjadi member, maka pembeli harus mendaftar dahulu sebagai member dengan mengisi Form Daftar Member. Pembeli dapat login dengan member yang telah dibuat apabila ingin belanja di lain waktu.

A2. Pembeli bisa memilih barang berdasarkan kategori.

A3. Pembeli memilih produk yang akan dibeli, bisa mengecek terlebih dahulu detail produknya, lalu ditambahkan ke keranjang belanja, sistem akan menampilkan jumlah barang dan total pembelian.

A4.Pembeli mencheckout keranjang belanja, sistem menampilkan nomor Faktur konfirmasi dan cara pembayaran.

A5. Pembeli melakukan konfirmasi pembayaran.

A6. Pembeli dapat mengecek konfirmasi pembayaran.

A7. Pembeli dapat mengecek status pembelian barang.

\section{Use Case Diagram Belanja Online}

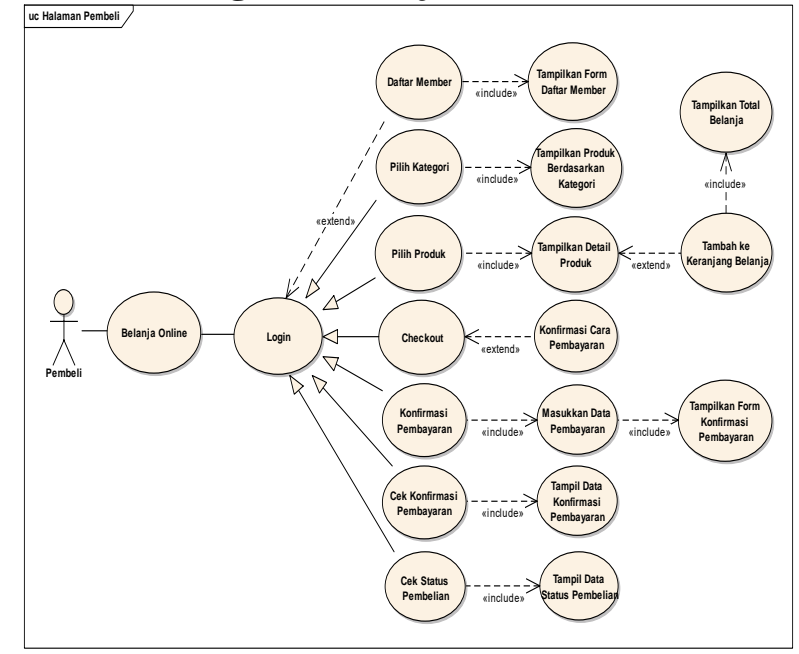

Gambar 1. Use Case Diagram Belanja Online 
Tabel 1. Deskripsi Use Case Diagram Penjualan Online

\begin{tabular}{|l|l|}
\hline \multicolumn{1}{|c|}{ Use Case Name } & \multicolumn{1}{c|}{ Belanja Online } \\
\hline Requirements & A1-A7 \\
\hline Goal & $\begin{array}{l}\text { Calon pembeli dapat melakukan pembelian secara } \\
\text { online via website }\end{array}$ \\
\hline Pre-conditions & Pembeli mengetahui situs dari sistem belanja online \\
\hline Post-conditions & Pembeli membeli barang secara online \\
\hline Failed end condition & Pembeli membatalkan belanja secara online \\
\hline Primary Actors & Calon pembeli \\
\hline Main Flow / Basic Path & 1. Pembeli memilih produk yang akan dibeli \\
\hline & 2. Pembeli menambahkan produk ke keranjang belanja \\
\hline & 3. Pembeli melakukan checkout \\
\hline & 4. Pembeli melakukan konfirmasi pembayaran via \\
web.
\end{tabular}

\section{Hasil dan Pembahasan}

\section{Implementasi Sistem}

\section{Perancangan Database}

Perancangan website ini menggunakan 13 (tiga belas) tabel yang terdapat dalam database couplefashiondb.sql yang nantinya akan digunakan dalam menjalankan website $e$ commerce Penjualan Fashion Berbasis Web pada H2H Couple Fashion.

\section{Tampilan Halaman Utama}

Setelah selesai dibuat, maka website dapat diakses secara online melalui www.h2honline.net63.net. Website $\mathrm{H} 2 \mathrm{H}$ Couple Fashion dapat dibuka dengan menggunakan web browser Mozilla firefox, google chrome, internet explorer, maupun opera mini.

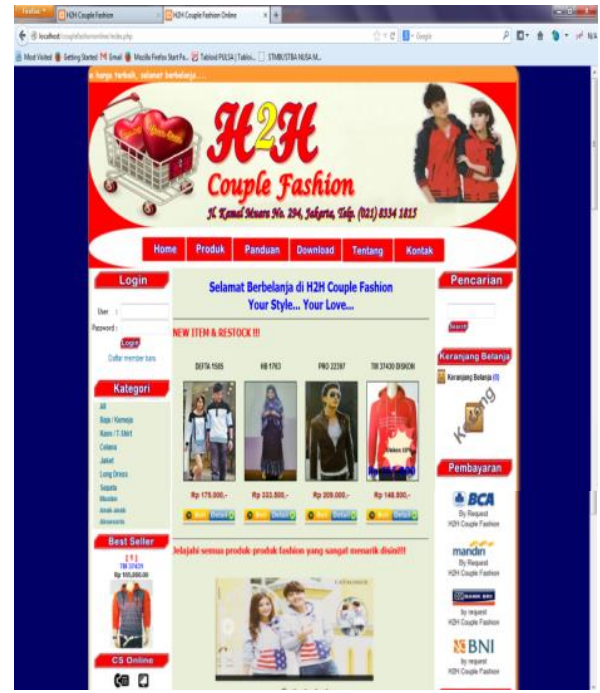

Gambar 2. Tampilan Halaman Utama
Tampilan Halaman Daftar Member

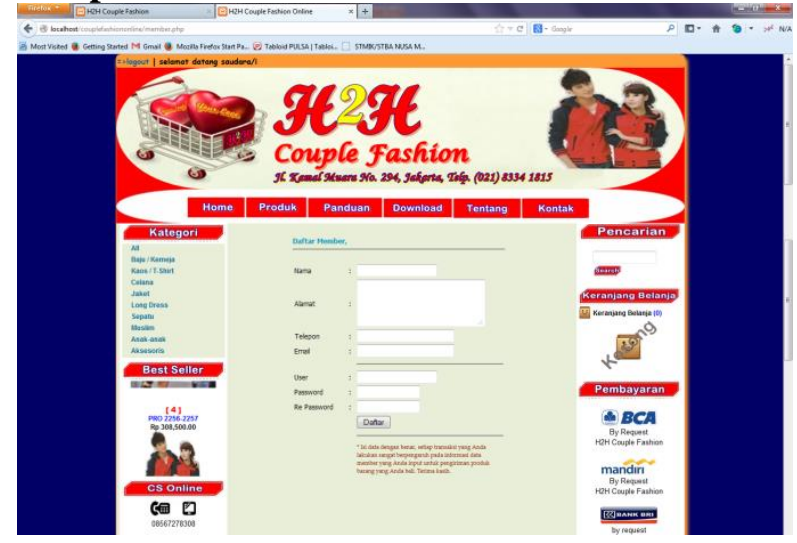

Gambar 3. Tampilan Halaman Daftar Member

Tampilan Halaman Login

\section{Login}

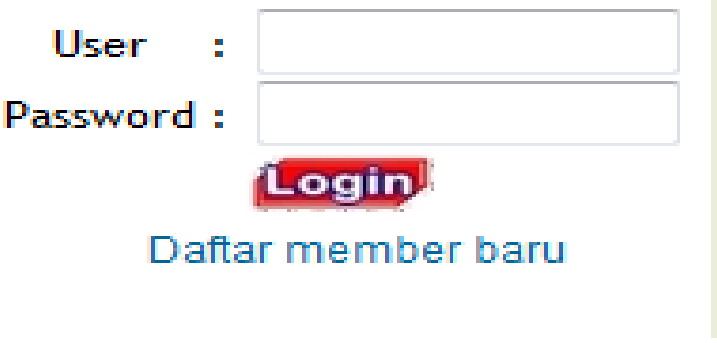

Gambar 4. Tampilan Halaman Login

\section{Tampilan Halaman Produk}

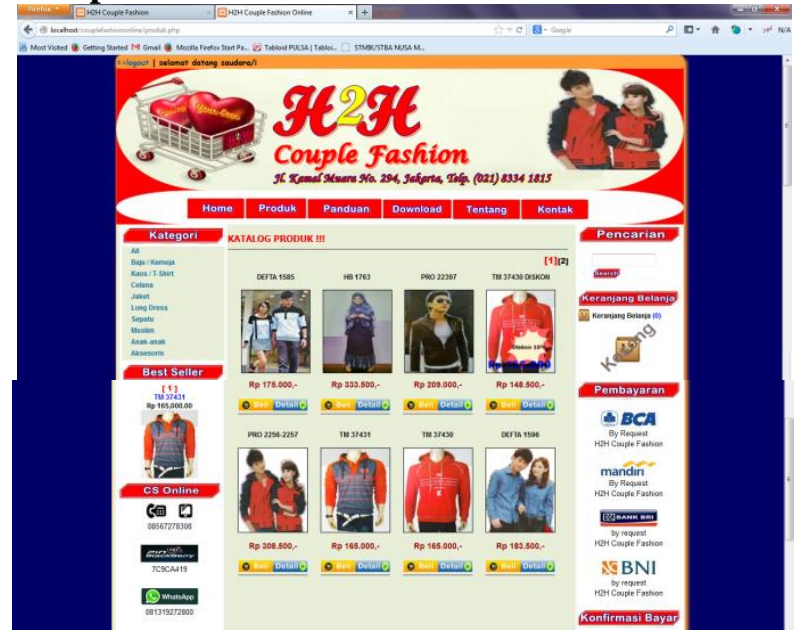

Gambar 5. Tampilan Halaman Produk 
Tampilan Halaman Keranjang Belanja

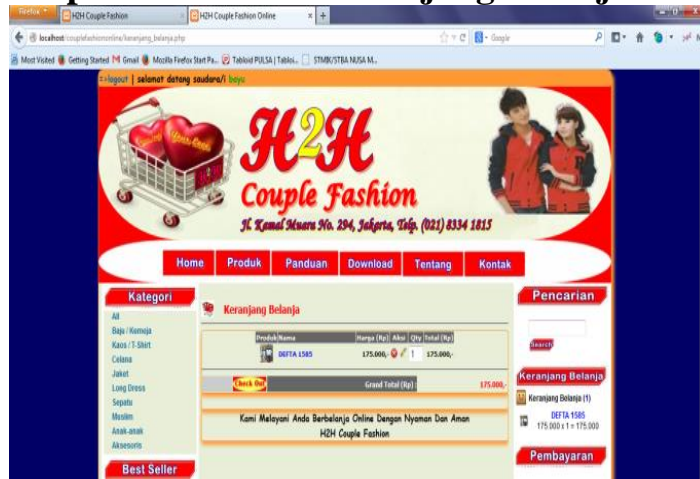

Gambar 6. Tampilan Halaman Keranjang Belanja

\section{Tampilan Halaman Transaksi Selesai}

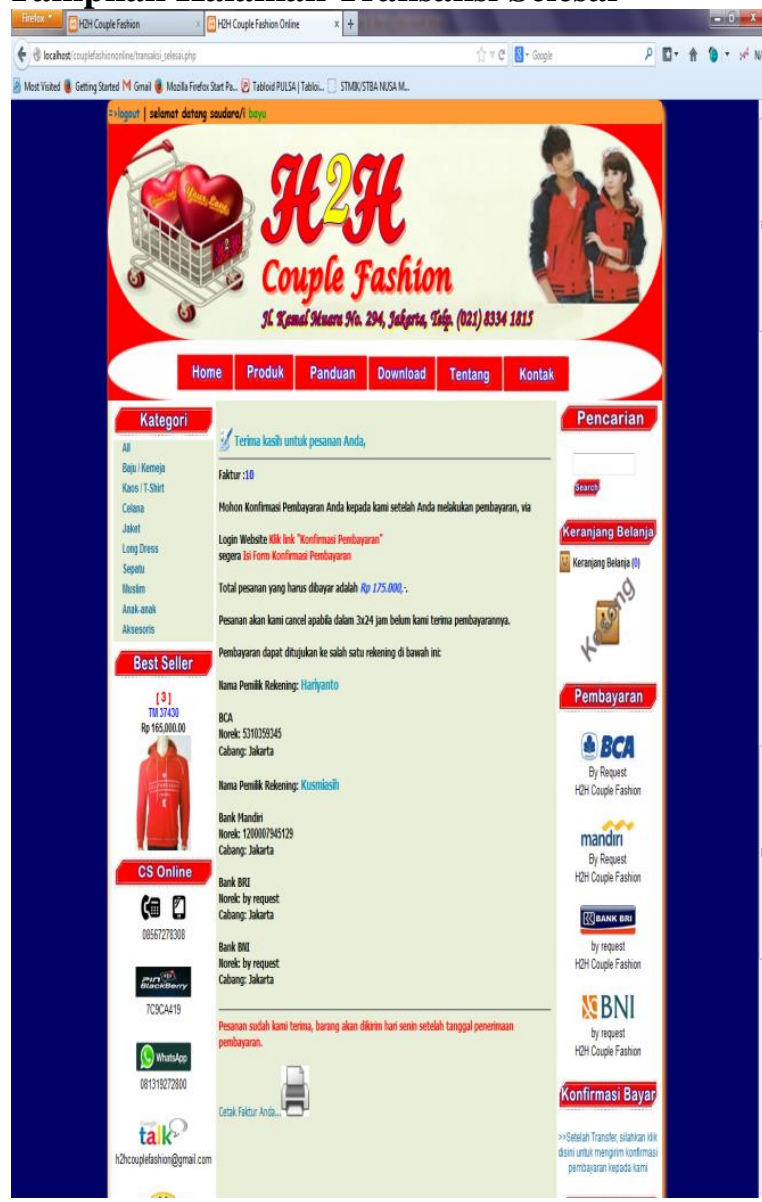

Gambar 7. Tampilan Halaman Transaksi Selesai
Tampilan Halaman Konfirmasi Pembayaran

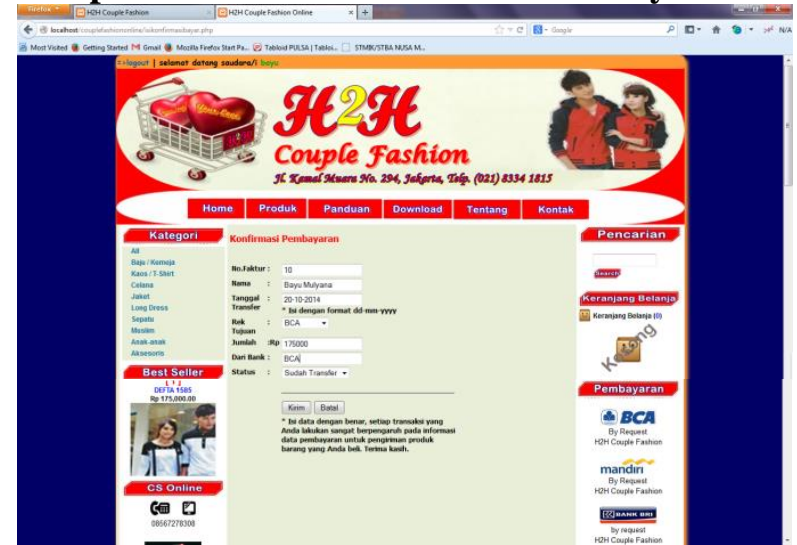

Gambar 8. Tampilan Halaman Konfirmasi Pembayaran

\section{Tampilan Halaman Testimonial}

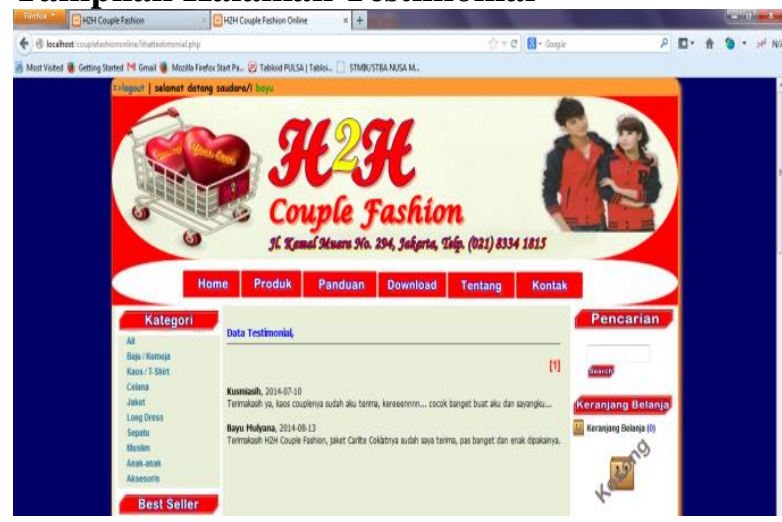

Gambar 9. Tampilan Halaman Testimonial

Tampilan Halaman Tentang

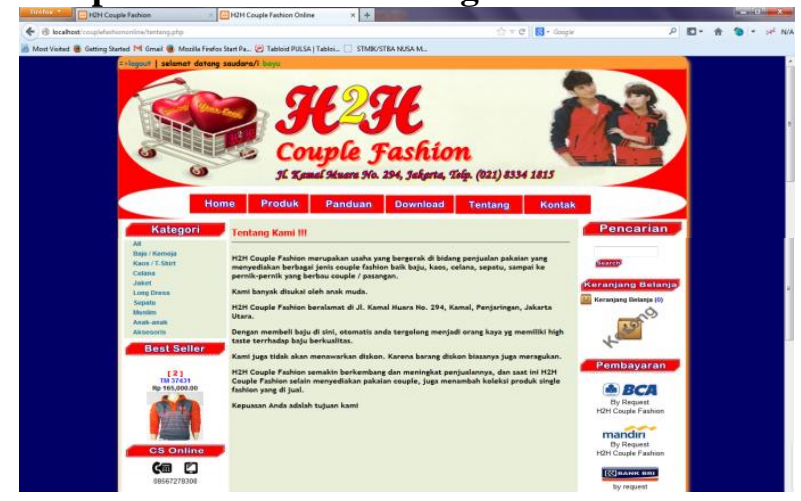

Gambar 10. Tampilan Halaman Tentang 
Tampilan Halaman Kontak

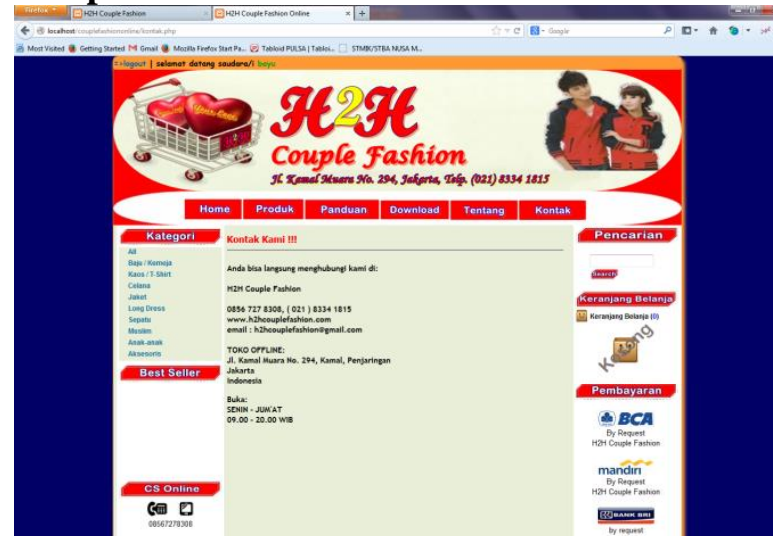

Gambar 11. Tampilan Halaman Kontak

\section{Kesimpulan dan Saran}

\section{Kesimpulan}

a. Sistem informasi penjualan online mudah diakses dari mana saja dan kapan saja.

b. Sistem informasi penjualan online menjadi sarana yang efektif dan efisien untuk mempromosikan produk secara cepat, murah, dengan jangkauan pasar yang luas hampir tak terbatas.

c. Sistem informasi penjualan online memudahkan penjual dan pembeli saling memberikan dan menerima informasi produk-produk baru secara cepat dan up to date.

d. Dengan tersedianya website sistem informasi penjualan, maka antara penjual dan pembeli dapat dengan cepat melakukan transaksi tanpa harus bertemu langsung sehingga menghemat waktu dan tenaga.

e. Sistem informasi penjualan online memudahkan perusahaan dalam mengelola produk, pelanggan, serta laporan-laporan sehingga selalu terkontrol.

\section{Saran}

a. Untuk lebih bisa menarik minat pengunjung dan pembeli, sebaiknya website penjualan online dibuat lebih menarik lagi.

b. Karena website penjualan online $\mathrm{H} 2 \mathrm{H}$ Couple Fashion masih baru, maka diperlukan promosi agar lebih banyak yang mengetahui keberadaan website tersebut, misalnya sering disebarkan di sosial media.

c. Fitur-fitur yang ada pada website penjualan online tersebut masih sangat sederhana, seperti detail produk berdasarkan yang tersedia, informasi mengenai pembayaran dan pengiriman barang, keamanan data member dan lain-lain agar dapat dijaga kerahasiannya, maka perlu pengembangan lebih jauh baik fitur maupun penerapan security sistem yang bagus.

\section{Daftar Pustaka}

Amin, Fatkhul, R. Soelistijadi dan Aji Priambodo. 2012. Aplikasi E-Commerce Sentra Batik di Kota Semarang Sebagai Salah satu Upaya Media Promosi dan Transaksi Secara Online. ISSN: 0854-9524. Semarang: Jurnal Imiah Unisbank Vol.17, No. 1 Januari 2012: 67-74.

Hastanti, Rulia Puji. 2014. Analisis dan Perancangan Sistem Penjualan Berbasis Web (E-Commerce) Pada Tata Distro Kabupaten Pacitan. ISSN: 2302-5700. Surakarta: Indonesian Journal on Networking and Security Vol. 3, No. 3 Juli 2014.

Marlinda, Linda, Sistem Basis Data, Andi Offset, Yogyakarta, 2004.

Rejeki, Rara Sri Artati, Agus Prasetyo Utomo dan Stefiana Sri Susanti. 2011. Perancangan dan Pengaplikasian Sistem Penjualan pada Distro Smith Berbasis E-Commerce. ISSN: 0854-9524. Semarang: urnal Ilmiah Unisbank Volume 16, No. 1 Juli 2011: 150159.

Sadeli, Muhammad, Toko Baju Online dengan PHP dan MySQL menggunakan Adobe Dreamweaver CS6, Maxikom, Palembang, 2013.

Sukamto, Rosa Ariani, Muhammad Shalahuddin, Rekayasa Perangkat Lunak, Modula, Bandung, 2011.

Sutabri, Tata. Pemrograman Terstruktur, Andi Publisher, Yogyakarta, 2004.

Warsiti. 2013. Pembuatan Website E-Commerce Usaha Fashion Fazza Shop Karanganyar. ISSN: 2302-1136. Karanganyar: Jurnal Ilmiah Unsa Vol. 2, No. 1 Maret 2013: 1217. 